\title{
Current Challenges in the Evaluation and Management of Hyponatremia
}

\author{
Kerri McGreal Pooja Budhiraja Nishank Jain Alan S.L. Yu \\ Division of Nephrology and Hypertension, The Kidney Institute, University of Kansas Medical Center, \\ Kansas City, Kans., USA
}

\section{Key Words}

Heart failure · Hyponatremia · Osmolality · Sodium .

Vasopressin

\begin{abstract}
Background: Hyponatremia is a common electrolyte imbalance that clinicians face on a regular basis. Summary: This review aims to discuss four current challenges that can arise when diagnosing and treating hyponatremia: low solute intake, heart failure, exercise-associated hyponatremia, and mild chronic hyponatremia. Low solute intake in a person who already has a urinary concentrating defect will lead to increased retention of free water. The free water retention will cause or worsen hyponatremia that is already present. Low solute intake is overlooked in patients with other disease processes that can cause hyponatremia, such as liver disease or heart failure. Heart failure and hyponatremia present their own set of challenges specifically with treatment as there are limited options. The newer class of aquaretics allows for the short-term treatment of hyponatremia. Exercise-associated hyponatremia is a phenomenon that has been described in ultra-endurance athletes. This happens when a person drinks a significant amount of water while exercising in the setting of antidiuretic hormone production
\end{abstract}

from prolonged exercise. This acute drop in sodium must be treated with hypertonic saline. The term asymptomatic mild chronic hyponatremia is no longer valid. Mild chronic hyponatremia carries an increased risk of falls and fractures, specifically in the elderly populations. Key Message: In summary, hyponatremia is a multifaceted disease and presents many challenges for physicians treating it.

(c) 2016 S. Karger AG, Basel

\section{Introduction}

Hyponatremia is defined as having a serum sodium $<135 \mathrm{mmol} / \mathrm{l}$. It is the most common electrolyte disorder seen in clinical practice [1]. Hyponatremia is related to a wide variety of etiologies and comorbidities. This can pose many dilemmas for a physician from the difficulty of recognizing the true underlying cause to deciding how and when to treat. This review article will address a num-

Contribution from the 1st Conference of the International Network of Diagnosis and Management of Acid-Base, Electrolyte and Fluid Alterations 'Diagnosis and Management of Acid-Base, Electrolyte and Fluid Alterations in Critically III Patients' held in Shanghai and Hangzhou on January 14-16, 2016.

\section{KARGER}

E-Mail karger@karger.com

www.karger.com/kdd
(C) 2016 S. Karger AG, Basel

2296-9381/16/0022-0056\$39.50/0
Alan S.L. Yu, MB, BChir

The Kidney Institute, University of Kansas Medical Center

3901 Rainbow Blvd, Mail Stop 3018

Kansas City, KS 66160 (USA)

E-Mail ayu@kumc.edu 
ber of current challenges in the diagnosis and treatment of hyponatremia. Specifically, we will discuss hyponatremia due to low solute intake, heart failure (HF) and hyponatremia, exercise-associated hyponatremia (EAH), and finally the morbidity and mortality associated with chronic mild hyponatremia.

\section{Low Solute Intake Is an Underrecognized Cause of Hyponatremia}

Most patients with hyponatremia excrete a hypotonic urine, with the major exception of severe syndrome of inappropriate antidiuretic hormone (SIADH). In this setting, the free water excretion rate is dependent on the urine volume which, in turn, is dependent on the solute excretion rate [2].

To appreciate this, consider the patient in table 1, who is unable to lower urine osmolality below $200 \mathrm{mOsm} / \mathrm{kg}$. Normal adults should be able to lower urinary osmolality below $100 \mathrm{mOsm} / \mathrm{kg}$, so this constitutes a mild defect in maximal urinary diluting ability. The effective osmolality or tonicity of the urine is the contribution of the electrolytes (primarily $\mathrm{Na}, \mathrm{K}$, and accompanying anions) to the osmolality, since urea is an ineffective osmole. In this particular patient, the urine tonicity is $140 \mathrm{mOsm} / \mathrm{kg}$ (table 1). Thus, the urine is approximately half isotonic. Put another way, each liter of urine contains 0.5 liters of electrolyte-free water.

The daily solute load that needs to be excreted in adults on a normal diet is $500-1,000 \mathrm{mOsm}$, which consists of urea generated from metabolism of dietary protein, and electrolytes. If this hypothetical patient had a daily solute load of $600 \mathrm{mOsm}$, he would excrete 3 liters of urine daily $(600 \mathrm{mOsm} / 200 \mathrm{mOsm} / \mathrm{kg})$ and hence 1.5 liters of electrolyte-free water daily (table 2). This patient would be highly unlikely to become hyponatremic with a normal daily water intake of 1.5 liters. If, on the other hand, the daily solute load was lowered to $300 \mathrm{mOsm}$ (e.g. due to poor dietary protein intake), the daily electrolyte-free water excretion would be only $750 \mathrm{ml}$. In this situation, a restriction of water intake to approximately $750 \mathrm{ml}$ daily would be needed to avoid progressive hyponatremia. Finally, a patient with a daily solute load of $150 \mathrm{mOsm}$ would have a daily electrolyte-free water excretion of 375 $\mathrm{ml}$ and would likely become progressively hyponatremic despite severe restriction of water intake.

The extreme manifestation of this is the rare condition of beer potomania, in which alcoholics who drink large amounts of fluid that is low in electrolytes, and have min-
Table 1. Calculation of urine osmolality and tonicity from urine electrolytes in a hypothetical patient

\begin{tabular}{lcl}
\hline & $\begin{array}{l}\text { Urine } \\
\text { concentration }\end{array}$ & $\begin{array}{l}\text { Osmolality, } \\
\text { mOsm } / \mathrm{kg}^{1}\end{array}$ \\
\hline $\mathrm{Na}$ & $50 \mathrm{mEq} / \mathrm{l}$ & 100 \\
$\mathrm{~K}$ & $20 \mathrm{mEq} / \mathrm{l}$ & 40 \\
Urea & $168 \mathrm{mg} / \mathrm{dl}$ & 60 \\
\hline Osmolality & & 200 \\
\hline Effective osmolality (tonicity) & & 140
\end{tabular}

${ }^{1}$ The osmolar contribution of electrolytes is equal to the $\mathrm{Na}$ and $\mathrm{K}$ concentrations (in $\mathrm{mmol} / \mathrm{l}$ ) $\times 2$ to account for accompanying anions, and the contribution of urea is equal to the concentration in $\mathrm{mg} / \mathrm{dl}$ divided by 2.8 .

Table 2. The daily osmolar load determines the electrolyte-free water clearance

\begin{tabular}{lll}
\hline $\begin{array}{l}\text { Total osmolar load needing } \\
\text { to be excreted, mOsm/day }\end{array}$ & $\begin{array}{l}\text { Obligate urine } \\
\text { output, } 1 / \text { day }^{1}\end{array}$ & $\begin{array}{l}\text { Electrolyte-free } \\
\text { water clearance, } \\
\text { 1/day }\end{array}$ \\
\hline 600 & 3 & 1.5 \\
300 & 1.5 & 0.75 \\
150 & 0.75 & 0.375 \\
\hline
\end{tabular}

${ }^{1}$ Assumes that the urine osmolality is $200 \mathrm{mOsm} / \mathrm{kg}$ and the tonicity is $140 \mathrm{mOsm} / \mathrm{kg}$ or approximately half of the serum tonicity.

imal protein intake, develop hyponatremia despite a normal urinary diluting ability [3-12]. This has also been described in patients on extreme weight-reducing diets that are very low in protein and high in water intake (e.g. a 'tea and toast' diet), which has been termed 'non-beer potomania' [13] or 'starvation potomania' [14].

What is underappreciated is that low solute intake is a common contributing factor to the hyponatremia in patients with other disorders that cause hyponatremia. In particular, patients with chronic HF and chronic liver failure are usually severely salt restricted and may have impaired appetite. Moreover, many such patients are elderly, live alone, and have severe functional limitations, which further limits the ability and motivation to prepare nutritious meals. These patients have a urinary diluting defect because of effective circulating volume depletion and stimulation of antidiuretic hormone $(\mathrm{ADH})$ secretion. However, we have noticed that many such patients 
have a relatively mild urinary diluting defect (much like the example in table 1) yet have disproportionately severe hyponatremia that is unexpectedly resistant to the primary treatment, which is fluid restriction. 'Potomania', in this context, is a misnomer because they frequently consume very little fluids either voluntarily or because of the prescribed fluid restriction.

This poses a challenging management problem because there are few other therapeutic options in such patients: salt tablets are usually contraindicated because of edema, tolvaptan is only approved for acute treatment for up to 1 month and is contraindicated in liver disease, and loop diuretics are effective at lowering a very high urine osmolality, but generally only down to $200-300 \mathrm{mOsm} /$ $\mathrm{kg}$ and no lower. In such patients, we have anecdotally had success in treating them with an increase in dietary protein intake. By so doing, one can increase urea generation, daily osmolar load, and hence daily free water excretion. Interestingly, this is physiologically equivalent to treating patients with urea, which has been used successfully to treat SIADH [15] but is considered too unpalatable for general clinical use.

How would one diagnose low solute intake in clinical practice? We recommend determining the daily solute excretion rate in all patients with hyponatremia. This can be determined from a 24-hour urine collection:

osmolar excretion rate $(\mathrm{mOsm} /$ day $)=$ urine osmolality

$(\mathrm{mOsm} / \mathrm{kg}) \times$ urine volume $(\mathrm{l} /$ day $)$.

Alternatively, it can be estimated from a spot urine by normalizing the urine osmolality to the creatinine concentration:

osmolar excretion rate $(\mathrm{mOsm} /$ day $)=$ urine osmolality

$(\mathrm{mOsm} / \mathrm{kg}) /$ urine $\mathrm{Cr}$ concentration $(\mathrm{mg} / \mathrm{dl}) \times 100$.

If the osmolar excretion rate is $<500 \mathrm{mOsm} / \mathrm{kg}$, the patient's protein intake should be estimated. This can be done either directly by evaluating self-reported dietary intake or indirectly from the measured urine urea content, using an estimating equation for protein nitrogen appearance [16]. If the patient's protein intake is low, measures to increase protein intake should be instituted to enhance free water excretion and improve the hyponatremia.

\section{Hyponatremia and HF}

Hyponatremia is a common occurrence in HF with an incidence around $20 \%$ in the subjects hospitalized for HF $[17,18]$. Cerebral edema is the most dreaded complica- tion of acute hyponatremia [19]. Even mild hyponatremia can cause cognitive and motor impairment. Cellular edema associated with hyponatremia could also affect cardiac function. Furthermore, it can limit optimum utilization of HF treatment including diuretics and reninangiotensin system blockers. Hyponatremia in HF has been noted to be associated with increased mortality, rehospitalizations, prolonged hospital stay, and major cardiovascular events $[18,20]$. However, it is unclear if hyponatremia is simply a marker of disease severity or if it plays a causal role.

Subjects with HF could present with depletional hyponatremia or hypervolemic hyponatremia [21]. Patients presenting with depletional hyponatremia are usually hypovolemic with an absolute deficiency of water but a relative excess of total body water compared with body sodium. They could be volume depleted due to poor intake, and diuretic use, especially thiazides, could have contributed to the persistent hyponatremic state. They will also present with urine $\mathrm{Na}<20 \mathrm{mmol} / \mathrm{l}$ unless accompanied by the recent use of a diuretic. Hyponatremia in these cases would respond initially to isotonic saline but may quickly worsen with further fluid administration in the presence of insuppressible ADH associated with HF. Hence, a cautious use of intravenous fluids is advised in this setting.

The common challenge in the setting of HF is hypervolemic hyponatremia. Hyponatremia in HF is multifactorial and results from increased angiotensin II, high sympathetic activity, and inappropriately high $\mathrm{ADH}$ from a decreased effective circulating volume [22-24]. There is lower solute and water delivered to the distal part of the nephron because of a decreased glomerular filtration rate from poor cardiac output as well as an increased proximal tubule absorption of solutes from increased adrenergic stimulation and angiotensin II. Decreased distal delivery of water leads to a decrease in the diluting capacity of the distal part of the nephron. Higher ADH further causes insertion of aquaporin and increases water permeability in the distal nephron. Thereby, urine studies show low osmolality and low urine sodium.

The available treatment options in chronic hyponatremia include fluid restriction, diuretics, and optimization of the HF regimen. Loop diuretics produce isotonic urine, and if fluid intake is not restricted, hyponatremia can worsen. Also, water restriction is poorly tolerated. Subjects may have a poor appetite and limited protein intake, which may further affect the urine-diluting capacity as described above. Other pharmacological therapies can be considered for hyponatremia in patients who respond poorly to the abovementioned therapeutic measures. 
Vaptans are aquaretics available for the management of hyponatremia [22]. Conivaptan is an intravenous aquaretic and inhibits both the $\mathrm{V}_{1}$ and the $\mathrm{V}_{2}$ receptor, while tolvaptan is an oral aquaretic and is a selective $V_{2}$ receptor antagonist. By blocking the $\mathrm{V}_{2}$ receptor, it blocks the activation of the receptor by endogenous ADH leading to solute-free water diuresis [25]. Unlike diuretics, vaptans improve sodium levels without compromising hemodynamics and impairing renal function, thereby allowing therapy for congestive HF including renin-angiotensin system blockade to be continued; thus, they appear to be an attractive option [17].

The Study of Ascending Levels of Tolvaptan in Hyponatremia (SALT-1 and SALT-2) trials evaluated tolvaptan compared to placebo for 30 days in euvolemic and hypervolemic hyponatremia. The study reported improvement in serum sodium and cognitive ability in the tolvaptan group [26]. Thirty percent of the subjects had congestive HF.

The Acute and Chronic Therapeutic Impact of a Vasopressin Antagonist in Congestive Heart Failure trial, another trial of vaptans, included 319 subjects admitted for HF. The subjects were randomized to 30,60 , and 90 $\mathrm{mg}$ of tolvaptan or placebo with a short-term follow-up of 60 days [17]. Twenty-one percent of the enrolled subjects with HF had hyponatremia. The 60 -day mortality did not improve with tolvaptan use compared to placebo except in subjects with higher blood urea nitrogen or severe volume overload. In a post hoc analysis of hyponatremic patients $(n=68)$, an improvement in serum sodium was associated with improved survival at 60 days [27].

Subsequently, in order to study the long-term effects of tolvaptan, the EVEREST trial was undertaken, which enrolled 4,133 subjects admitted for HF [28]. There was no significant improvement in mortality or re-hospitalization rates with tolvaptan. The authors reported that among all hyponatremic subjects with serum sodium $<135 \mathrm{mmol} / \mathrm{l}$, there was no effect of tolvaptan on the long-term mortality except in those subjects with serum sodium $<130 \mathrm{mmol} / \mathrm{l}(\mathrm{n}=92 ; 38$ in the tolvaptan and 54 in the placebo group; $\mathrm{p}=0.04)$ where it was associated with an improvement in cardiovascular morbidity and mortality [29]. Only $8 \%$ of the enrolled subjects had hyponatremia, and the trial was not adequately powered to examine outcomes in this subgroup analysis of subjects with hyponatremia and HF. Hence, there are limited long-term data available on the mortality benefit and hospitalizations in hyponatremic HF patients. Studies specifically examining the association between mortality rate and the effect of sodium improvement in this population are needed.

Vaptans are also associated with a dry mouth, increased thirst, and carry the risk of serum sodium overcorrection [17]. Due to an increased risk of overcorrection, it is recommended that the therapy be started in the hospital at a lower dose of $15 \mathrm{mg}$ daily with dose up-titration as tolerated. Fluid should not be restricted during the initial phase. In the US, tolvaptan has been approved in patients with serum sodium $<125 \mathrm{mmol} / \mathrm{l}$, unless patients are symptomatic and not responding to fluid restriction and diuretics. It is only approved for a 30-day period due to the finding of hepatic injury in autosomal dominant polycystic kidney disease subjects [30]. Vaptans could be especially useful for a short-term use in subjects with acute decompensated HF associated with worsening hyponatremia not responding to diuretics.

HF subjects presenting with acute symptomatic hyponatremia present a challenging situation for treating physicians. Hypertonic saline with intravenous loop diuretics is an available option provided patients have demonstrated an adequate response to diuretics; otherwise, it could worsen the volume status. Hypertonic saline with diuretics has been used in subjects presenting with acute decompensated HF and was noted to improve serum sodium compared to diuretic alone [31].

In subjects with hyponatremia and renal failure in the setting of acute decompensated HF, diuretics and vaptans may not work due to decreased fluid delivery to the renal tubules. Hypertonic saline may worsen fluid status, and renal replacement therapy is the only viable option in these subjects. Hemodialysis or sustained low-efficiency dialysis with a low flow rate and a lower dialysate sodium concentration could be used, depending on the serum sodium level, to achieve the required sodium correction as recommended by the therapeutic guidelines [32]. Continuous renal replacement therapy can be used and provide a slower rate of correction. Sterile water can be added or replaced in the available standard replacement/dialysate bags $[33,34]$.

Management of hyponatremia in subjects with HF can be challenging due to limited options and no significant long-term data on improvement in mortality with the available treatment. The treatment should be individualized depending on the severity and acuteness of the disease, and large randomized controlled trials evaluating hyponatremia treatment and its effect on outcomes are clearly warranted. 


\section{Exercise-Associated Hyponatremia}

EAH was not known prior to 1981, when a recommendation appeared that suggested to drink as much water as possible during exercise [35]. EAH (serum sodium $<135$ $\mathrm{mmol} / \mathrm{l}$ ) is noted in up to $7 \%$ of ultra-endurance athletes or marathon runners. These athletes drink high rates of water, which results in weight gain instead of weight loss from burning tissue glycogen with prolonged-endurance physical activity [36]. It is further promoted by a common belief that drinking sports drinks, which have a sodium concentration $<20 \mathrm{mmol} / \mathrm{l}$, will offset this risk, whereas drinking tap water may induce EAH. High consumption of tap water or electrolyte-free water is probably not enough to generate EAH. Its generation is facilitated by nonosmotic stimuli from prolonged-endurance physical activity that result in elevated plasma arginine vasopres$\sin (\mathrm{AVP})$ or ADH. This concept was reported by HewButler et al. [37] in 82 trained marathon runners before and after a $56-\mathrm{km}$ marathon in South Africa. The authors reported plasma AVP levels to be elevated in all marathon runners with or without a decrease in serum sodium concentrations. The same group reported a 4 -fold increase in plasma AVP levels associated with a $2 \mathrm{mmol} / \mathrm{l}$ decrease in serum sodium concentration and a marginal (5\%) contraction in plasma volume among 33 cyclists who completed a $109-\mathrm{km}$ race [38]. Siegel et al. [39] reported similar findings of elevated plasma AVP levels in 22 collapsed Boston marathon runners with EAH compared to 33 marathon runners without EAH. These studies suggest that $\mathrm{EAH}$ in runners mimics SIADH in the clinical presentation with the presence of inappropriately high plasma AVP levels and high urine osmolalities.

To evaluate what triggers the nonosmotic release of AVP in marathon runners with EAH, Hew-Butler et al. [37] measured plasma AVP, cytokines, and endocrine hormones before and after the marathon. They reported high plasma AVP levels to be directly related to exerciseinduced plasma volume contraction and partly influenced by plasma oxytocin, brain natriuretic peptide, and corticosterone levels. Although serum interleukin-6, generated by muscle contractions, can stimulate AVP production in humans, the study failed to establish an association between high interleukin-6 levels and plasma AVP. These findings were confirmed by Siegel et al. [39] in Boston marathon runners.

Of 96 marathon runners studied over 4 Houston marathons, 22\% were found to have asymptomatic EAH [40]. Runners who developed asymptomatic EAH were 7 times more likely to have lost $<0.75 \mathrm{~kg}$ of body weight than those without EAH, who were noted to have lost $\geq 0.75 \mathrm{~kg}$ of their body weight. Although the sweat rate is regulated by various factors including intensity of exercise, body weight, and degree of acclimatization, high water consumption, exceeding the amount that is lost, is more likely to happen in an untrained light-weight runner. Based on the findings from Chorley et al. [40] and the mechanisms regulating the sweat rate, the authors identified low-body weight runners, especially those $\leq 60-65 \mathrm{~kg}$, as being at an increased risk of symptomatic EAH.

Finally, the jury is still out regarding whether nonsteroidal anti-inflammatory drug (NSAID) use increases the risk of developing EAH. Up to $20 \%$ of runners use NSAIDs [41]. However, no changes in the rates of EAH were reported in those who used NSAIDs compared to those who did not use the drugs [41]. As promoted by the global sports drink industry, some athletes drink large volumes of water prior to physical activities to avoid dehydration, and others drink up to $3 \mathrm{l} / \mathrm{h}$ to dilute urine-specific gravity in order to clear the screening of banned drugs in the urine. These practices remain common and increase the risk of symptomatic EAH.

For the treatment of symptomatic EAH, the Second International EAH Consensus Development Conference, Queensland, New Zealand, 2007, recommended the use of a 100 - $\mathrm{ml}$ bolus infusion of $3 \%$ saline with up to 2 additional bolus doses at 10-min intervals to reduce cerebral edema in acute EAH with encephalopathy. The international experts reviewed cases of EAH encephalopathy and found that 2 previously healthy runners who received isotonic saline infusion did not survive, whereas runners with symptomatic EAH who received hypertonic saline experienced a rise in the serum sodium concentration by 4-6 mmol/l, resulting in clinical improvement without sequel $[39,42]$. Runners that can drink may be given 4 bouillon cubes mixed in $4 \mathrm{oz}$ of water to accomplish similar changes in serum sodium concentration [43].

\section{Morbidity and Mortality Associated with Chronic Mild Hyponatremia}

Hyponatremia under certain conditions has been associated with significant morbidity and mortality. Acute and severe hyponatremia is a medical emergency that carries a high mortality rate. The overall in-hospital mortality is increased in patients who are hyponatremic [44]. A large cohort study looked at both community-acquired and hospital-acquired hyponatremia and found both to be associated with an increase in mortality [44]. Hypona- 
tremia is a poor prognostic factor in patients with endstage liver disease as well as advanced HF [45-47]. Asymptomatic chronic mild and moderate hyponatremia has previously been thought to be inconsequential, specifically in an elderly population. However, recent data discussed below have shown that this might not be true.

Falls present a major health problem for elderly patients with approximately $30 \%$ of people over the age of 65 years falling every year [48]. Falls are not trivial in elderly persons; fractures will occur in $2-4 \%$ of falls, and death from a complication of a fracture will occur in $2 \%$ of cases [49]. Hyponatremic patients have a significantly increased risk of falls when compared to patients with normal serum sodium concentration [50]. Patients experience a $32 \%$ higher risk of falls if their serum sodium concentration drops from 135 to $130 \mathrm{mmol} / \mathrm{l}$ [51]. One possible theory for the increased risk of falls is the gait and attention deficits found in hyponatremic patients. Gait was assessed in patients who were hyponatremic (mean serum sodium of $128 \mathrm{mmol} / \mathrm{l}$ ), and they were found to exhibit trouble taking steps in tandem [50]. These same patients' gaits were assessed after correction of serum sodium, and most had notable improvement. Patients were then compared to age- and sex-matched controls with a blood alcohol level of $0.6 \mathrm{~g} / \mathrm{l}$, and the hyponatremic patients did worse [50]. Mental alertness has also been looked at, and the researchers found that hyponatremic patients had deficits in their attention when compared to the normal controls. Interestingly, attention was worse than in alcohol-intoxicated age- and sex-matched controls [50]. Studies in animal models support hyponatremia as a cause of gait abnormalities and cognitive deficits. Following induction of chronic hyponatremia, the rats developed gait abnormalities and memory deficits [52]. Overall, patients with mild chronic hyponatremia have an increased risk of falls possibly due to gait abnormalities and cognitive deficits.

The risk of fractures from falls was looked at in a casecontrol study which found that people who had chronic hyponatremia had a higher risk of fractures from falls than patients who had a normal serum sodium concentration [49]. A prospective study was also done using the Rotterdam Study cohort to assess the association of mild chronic hyponatremia (mean serum sodium of 133.4 $\mathrm{mmol} / \mathrm{l}$ ) with fractures. Hoorn et al. [53] found that there were increased fractures, specifically nonvertebral fractures, in people with chronic hyponatremia. It is possible that chronic hyponatremia can cause osteoporosis, which would place a hyponatremic patient at increased risk of fractures. National Health and Nutrition Examination
Survey (NHANES) data were assessed, and it was found that there is an increase in the prevalence of osteoporosis in patients who are hyponatremic [54]. In SIADH rat models, rats that were chronically hyponatremic had a $30 \%$ reduction in bone mass at 3 months in comparison with SIADH rats that were not hyponatremic [54]. Notably, osteoporosis cannot be the only reason for the observed increased risk of fractures in chronic hyponatremia, as Hoorn et al. [53] in their prospective study found no differences in the bone mineral densities of people who had mild chronic hyponatremia compared to those who had normal serum sodium. A cross-sectional study was done that showed an increased risk of fractures independent of osteoporosis in patients with hyponatremia [55]. Hyponatremic patients have an increased risk of fractures, and this is in part due to hyponatremia-induced osteoporosis, but other factors are likely contributing as well.

Mild chronic hyponatremia in elderly patients is not asymptomatic. There is increasing evidence which shows that patients experience discrepancies in gait and cognition, in addition to increased risk of falls, fractures, and osteoporosis. The elderly population has a higher prevalence of chronic hyponatremia [56]. It is unclear whether correcting their serum sodium will improve their mortality associated with chronic hyponatremia [53]. There is supporting evidence that correcting serum sodium can potentially improve quality of life $[26,50]$.

\section{Conflict of Interest Statement}

The authors declare that they have no conflicts of interest.

References
1 Upadhyay A, Jaber BL, Madias NE: Incidence and prevalence of hyponatremia. Am J Med 2006;119(7 suppl 1):S30-S35.

-2 Berl T: Impact of solute intake on urine flow and water excretion. J Am Soc Nephrol 2008; 19:1076-1078.

3 Demanet JC, Bonnyns M, Bleiberg H, Stevens-Rocmans C: Coma due to water intoxication in beer drinkers. Lancet 1971;2:11151117.

-4 Hilden T, Svendsen TL: Hypo-osmolality in beer drinkers. Lancet 1975;2:822.

5 Hilden T, Svendsen TL: Electrolyte disturbances in beer drinkers. A specific 'hypo-osmolality syndrome'. Lancet 1975;2:245-246.

-6 Joyce SM, Potter R: Beer potomania: an unusual cause of symptomatic hyponatremia. Ann Emerg Med 1986;15:745-747. 
7 Harrow AS: Beer potomania syndrome in an $>23$ Cohn JN, Levine TB, Francis GS, Goldsmith alcoholic. Va Med 1989;116:270-271.

8 Harrow AS: Beer potomania. South Med J 1995;88:602.

9 Fenves AZ, Thomas S, Knochel JP: Beer potomania: two cases and review of the literature. Clin Nephrol 1996;45:61-64.

10 Bhattarai N, Kafle P, Panda M: Beer potomania: a case report. BMJ Case Rep 2010;2010.

11 Kujubu DA, Khosraviani A: Beer potomania - an unusual cause of hyponatremia. Perm J 2015;19:74-76.

$\checkmark 12$ Pallavi R: An unsuspected cause of hyponatremia: beer potomania. J Am Geriatr Soc 2015;63:1714-1715.

13 Thaler SM, Teitelbaum I, Berl T: 'Beer potomania' in non-beer drinkers: effect of low dietary solute intake. Am J Kidney Dis 1998;31: 1028-1031.

14 Imam TH: Taking alcohol with a (large) pinch of salt: understanding the osmoles in 'beer potomania' and 'starvation potomania'. Indian J Nephrol 2014;24:203-205.

$\checkmark 15$ Soupart A, Coffernils M, Couturier B, Gankam-Kengne F, Decaux G: Efficacy and tolerance of urea compared with vaptans for long-term treatment of patients with SIADH. Clin J Am Soc Nephrol 2012;7:742-747.

16 Maroni BJ, Steinman TI, Mitch WE: A method for estimating nitrogen intake of patients with chronic renal failure. Kidney Int 1985; 27:58-65.

17 Gheorghiade M, Gattis WA, O'Connor CM, Adams KF Jr, Elkayam U, Barbagelata A, Ghali JK, Benza RL, McGrew FA, Klapholz M, Ouyang J, Orlandi C; Acute and Chronic Therapeutic Impact of a Vasopressin Antagonist in Congestive Heart Failure (ACTIV in CHF) Investigators: Effects of tolvaptan, a vasopressin antagonist, in patients hospitalized with worsening heart failure: a randomized controlled trial. JAMA 2004;291:1963-1971.

- 18 Balling L, Schou M, Videbaek L, Hildebrandt P, Wiggers H, Gustafsson F; Danish Heart Failure Clinics Network: Prevalence and prognostic significance of hyponatraemia in outpatients with chronic heart failure. Eur J Heart Fail 2011;13:968-973.

$\checkmark 19$ Adrogue HJ, Madias NE: Hyponatremia. N Engl J Med 2000;342:1581-1589.

20 Gheorghiade M, Rossi JS, Cotts W, Shin DD, Hellkamp AS, Pina IL, Fonarow GC, DeMarco T, Pauly DF, Rogers J, DiSalvo TG, Butler J, Hare JM, Francis GS, Stough WG, O'Connor $\mathrm{CM}$ : Characterization and prognostic value of persistent hyponatremia in patients with severe heart failure in the ESCAPE trial. Arch Intern Med 2007;167:1998-2005.

21 Verbrugge FH, Steels P, Grieten L, Nijst P, Tang WH, Mullens W: Hyponatremia in acute decompensated heart failure: depletion versus dilution. J Am Coll Cardiol 2015;65: 480-492.

-22 Schrier RW: Treatment of hyponatremia. N Engl J Med 1985;312:1121-1123.
S: Neurohumoral control mechanisms in congestive heart failure. Am Heart J 1981; 102(3 Pt 2):509-514.

24 Schrier RW, Abraham WT: Hormones and hemodynamics in heart failure. N Engl J Med 1999;341:577-585.

25 Doggrell SA: Tolvaptan (Otsuka). Curr Opin $>37$ Investig Drugs 2004;5:977-983.

26 Schrier RW, Gross P, Gheorghiade M, Berl T, Verbalis JG, Czerwiec FS, Orlandi C: Tolvap$\tan$, a selective oral vasopressin $\mathrm{V}_{2}$-receptor antagonist, for hyponatremia. N Engl J Med 2006;355:2099-2112.

27 Rossi J, Bayram M, Udelson JE, Lloyd-Jones D, Adams KF, Oconnor CM, Stough WG, Ouyang J, Shin DD, Orlandi C, Gheorghiade M: Improvement in hyponatremia during hospitalization for worsening heart failure is associated with improved outcomes: insights from the Acute and Chronic Therapeutic Impact of a Vasopressin Antagonist in Chronic Heart Failure (ACTIV in CHF) trial. Acute Cardiac Care 2007;9:82-86.

28 Konstam MA, Gheorghiade M, Burnett JC Jr, Grinfeld L, Maggioni AP, Swedberg K, Udelson JE, Zannad F, Cook T, Ouyang J, Zimmer C, Orlandi C: Effects of oral tolvaptan in patients hospitalized for worsening heart failure: the EVEREST Outcome Trial. JAMA 2007;297:1319-1331.

-29 Hauptman PJ, Burnett J, Gheorghiade M, Grinfeld L, Konstam MA, Kostic D, Krasa HB, Maggioni A, Ouyang J, Swedberg K, Zannad F, Zimmer C, Udelson JE: Clinical course of patients with hyponatremia and decompensated systolic heart failure and the effect of vasopressin receptor antagonism with tolvaptan. J Card Fail 2013;19:390-397.

30 Torres VE, Chapman AB, Devuyst O, Gansevoort RT, Grantham JJ, Higashihara E, Perrone RD, Krasa HB, Ouyang J, Czerwiec FS: Tolvaptan in patients with autosomal dominant polycystic kidney disease. N Engl J Med 2012;367:2407-2418.

31 Licata G, Di Pasquale P, Parrinello G, Cardinale A, Scandurra A, Follone G, Argano C, Tuttolomondo A, Paterna S: Effects of highdose furosemide and small-volume hypertonic saline solution infusion in comparison with a high dose of furosemide as bolus in refractory congestive heart failure: long-term effects. Am Heart J 2003;145:459-466.

32 Wendland EM, Kaplan AA: A proposed approach to the dialysis prescription in severely hyponatremic patients with end-stage renal disease. Semin Dial 2012;25:82-85.

33 Bender FH: Successful treatment of severe hyponatremia in a patient with renal failure using continuous venovenous hemodialysis. Am J Kidney Dis 1998;32:829-831.

34 Yessayan L, Yee J, Frinak S, Szamosfalvi B: Treatment of severe hyponatremia in patients with kidney failure: role of continuous venovenous hemofiltration with low-sodium replacement fluid. Am J Kidney Dis 2014;64: 305-310.
35 Rosner MH, Kirven J: Exercise-associated hyponatremia. Clin J Am Soc Nephrol 2007;2: 151-161.

36 Beltrami FG, Hew-Butler T, Noakes TD: Drinking policies and exercise-associated hyponatraemia: is anyone still promoting overdrinking? Br J Sports Med 2008;42:796-801.

7 Hew-Butler T, Jordaan E, Stuempfle KJ, Speedy DB, Siegel AJ, Noakes TD, Soldin SJ, Verbalis JG: Osmotic and nonosmotic regulation of arginine vasopressin during prolonged endurance exercise. J Clin Endocrinol Metab 2008;93:2072-2078.

38 Hew-Butler T, Dugas JP, Noakes TD, Verbalis JG: Changes in plasma arginine vasopressin concentrations in cyclists participating in a 109-km cycle race. Br J Sports Med 2010;44: 594-597.

39 Siegel AJ, Verbalis JG, Clement S, Mendelson JH, Mello NK, Adner M, Shirey T, Glowacki J, Lee-Lewandrowski E, Lewandrowski KB: Hyponatremia in marathon runners due to inappropriate arginine vasopressin secretion. Am J Med 2007;120:461.e11-e17.

40 Chorley J, Cianca J, Divine J: Risk factors for exercise-associated hyponatremia in nonelite marathon runners. Clin J Sport Med 2007;17:471-477.

41 Page AJ, Reid SA, Speedy DB, Mulligan GP, Thompson J: Exercise-associated hyponatremia, renal function, and nonsteroidal antiinflammatory drug use in an ultraendurance mountain run. Clin J Sport Med 2007;17:43-48.

42 Hew-Butler T, Anley C, Schwartz P, Noakes $\mathrm{T}$ : The treatment of symptomatic hyponatremia with hypertonic saline in an Ironman triathlete. Clin J Sport Med 2007;17:68-69.

43 Rogers IR, Hook G, Stuempfle KJ, Hoffman MD, Hew-Butler T: An intervention study of oral versus intravenous hypertonic saline administration in ultramarathon runners with exercise-associated hyponatremia: a preliminary randomized trial. Clin J Sport Med 2011; 21:200-203.

44 Wald R, Jaber BL, Price L, Upadhyay A, Madias NE: Impact of hospital-associated hyponatremia on selected outcomes. Arch Intern Med 2010;170:294-302.

45 Corona G, Giuliani C, Parenti G, Norello D, Verbalis JG, Forti G, Maggi M, Peri A: Moderate hyponatremia is associated with increased risk of mortality: evidence from a meta-analysis. PLoS One 2013;8:e80451.

46 Abramowicz M: Hyponatremia and mortality among patients waiting for liver transplantation. N Engl J Med 2008;359:2615; author reply 2615.

47 Klein L, O’Connor CM, Leimberger JD, Gattis-Stough W, Pina IL, Felker GM, Adams KF Jr, Califf RM, Gheorghiade M: Lower serum sodium is associated with increased shortterm mortality in hospitalized patients with worsening heart failure: results from the Outcomes of a Prospective Trial of Intravenous Milrinone for Exacerbations of Chronic Heart Failure (OPTIME-CHF) study. Circulation 2005;111:2454-2460. 
48 Tinetti ME, Speechley M, Ginter SF: Risk factors for falls among elderly persons living in the community. N Engl J Med 1988;319: 1701-1707.

-49 Gankam Kengne F, Andres C, Sattar L, Melot C, Decaux G: Mild hyponatremia and risk of fracture in the ambulatory elderly. QJM 2008; 101:583-588.

50 Renneboog B, Musch W, Vandemergel X, Manto MU, Decaux G: Mild chronic hyponatremia is associated with falls, unsteadiness, and attention deficits. Am J Med 2006;119:71. e1-e8.

51 Gunathilake R, Oldmeadow C, McEvoy M, Kelly B, Inder K, Schofield P, Attia J: Mild hy- ponatremia is associated with impaired cognition and falls in community-dwelling older persons. J Am Geriatr Soc 2013;61:1838-1839. 52 Fujisawa H, Sugimura Y, Takagi H, Mizoguchi $\mathrm{H}$, Takeuchi $\mathrm{H}$, Izumida $\mathrm{H}$, Nakashima $\mathrm{K}$, Ochiai H, Takeuchi S, Kiyota A, Fukumoto K, Iwama S, Takagishi $\mathrm{Y}$, Hayashi $\mathrm{Y}$, Arima $\mathrm{H}$, Komatsu Y, Murata Y, Oiso Y: Chronic hyponatremia causes neurologic and psychologic impairments. J Am Soc Nephrol 2016;27: 766-780.

53 Hoorn EJ, Rivadeneira F, van Meurs JB, Ziere G, Stricker BH, Hofman A, Pols HA, Zietse R, Uitterlinden AG, Zillikens MC: Mild hyponatremia as a risk factor for fractures: the Rot- terdam Study. J Bone Miner Res 2011;26: 1822-1828.

54 Verbalis JG, Barsony J, Sugimura Y, Tian Y, Adams DJ, Carter EA, Resnick HE: Hyponatremia-induced osteoporosis. J Bone Miner Res 2010;25:554-563.

55 Kinsella S, Moran S, Sullivan MO, Molloy MGM, Eustace JA: Hyponatremia independent of osteoporosis is associated with fracture occurrence. Clin J Am Soc Nephrol 2010; 5:275-280.

56 Mohan S, Gu S, Parikh A, Radhakrishnan J: Prevalence of hyponatremia and association with mortality: results from NHANES. Am J Med 2013;126:1127-1137.e1. 